\title{
Solidární zisk a efektivita lásky. Motivy současné katolické etiky tržního hospodář́ství Vojtěch Mašek
}

V ř́ínu 2015, krátce po vypuknutí aféry s falšováním emisních údajů u automobilů Volkswagen, vydal generální manažer této firmy v USA Michael Horn následující prohlášení: „Nebylo to firemní rozhodnutí, nekonala se žádná schůze vedení, která by to schválila. Bylo to pár inženýrů, kteří se z nějakého důvodu rozhodli software nainstalovat. “" Ředitel společnosti Citigroup, známé poskytováním rizikových úvěrů nesolventním klientům za vysoké úroky, popsal základní poselství své práce pro změnu slovy: „Když přestane hrát hudba /ve smyslu platební schopnosti/2 , ...) situace se zkomplikuje, dokud však hudba hraje, musíte se zvednout a jít tančit.“3 Oba výroky vedou prakticky uvažujícího člověka ke zdánlivě jednoznačnému závěru; aby dosáhl hospodářského úspěchu, musí se nutně chovat neeticky, a aby si zachoval mravní charakter, musí jednat „neekonomicky“, tj. proti vlastnímu zájmu a prospěchu. Nespokojíme-li se však s pragmatickým cynismem ani s planým morálním rozhořčením, mohou se nám tyto výroky stát podnětem $\mathrm{k}$ hlubší úvaze o možnosti uplatnění morálky $\mathrm{v}$ hospodářství a hospodářské racionality $\mathrm{v}$ morálce, a tak přispět $\mathrm{k}$ plastičtějšímu pohledu na celek lidského jednání. Klíčovou otázkou této studie proto bude, $z d a$ a jak je v podmínkách současného globálního tržního hospodářství možná hospodářská etika a zejména $\mathrm{v}$ čem př́padně tkví specifický prínos katolické tradice a života $\mathrm{z}$ víry pro tuto etiku.

Vyjasnění těchto dvou témat však nejprve předpokládá vyrovnání s fenoménem etiky jako takové. Je třeba si přiznat, že etika se v „postmoderní“ pluralitní společnosti stala krajně nesamozřejmou. Je předmětem neustálých a do značné míry oprávněných pochybností, tápání a sporů, které vedly některé humanitní vědce až k závěru, že etiku je třeba $\mathrm{z}$ rozumových úvah zcela vyškrtnout (Niklas Luhmann, John Caputo) nebo ji chápat pouze jako projekt odvozený z jiných disciplín, např. z psychologie, sociologie, filosofie nebo teologie. V oblasti myšlení dnes stěží existuje disciplína, která by byla více podceňovaná než etika, a přesto je mravní hodnocení vždy první po ruce všude tam, kde člověku v životě „dochází řeč“ nebo kde se ocitá ve střetu s neúprosnou lidskou realitou. Je proto na místě se ptát, zda nemá poznání (včetně nejrozmanitějších forem hospodářské racionality) vždy v určitém smyslu také mravní povahu, a zda může dokonce existovat svébytné „etické vědění“.

V čem by mohlo takové vědění spočívat? Uznáme-li nutnost každého myslitele vždy zároveň „přebývat ve zkoumané realitě“, musíme do jisté míry připustit, že vědomí a svědomí jsou bytostně neoddělitelné a že otázka po dobrém životě je jedním z ohnisek, z nichž naše rozumové

() National Cable Satellite Corporation, Volkswagen Emissions Investigation (on-line), dostupné na: http://www.c-span.org/video/?328599-1/hearing-volkswagen-emissions-violations, citováno dne 19. 7. 2016.

2 Poznámka autora.

3 Cit. dle: John CASSIDY, Jak selhávají trhy: Logika ekonomických kalamit, Praha: Academia, 2012, s. 18. 
tázání vychází a k nimž se musí neustále vracet. ${ }^{4}$ Etika je navzdory své křehkosti a konfliktnosti jedním ze základních náhledů na skutečnost usilujícím o dosažení jednoty mezi myšlením, řečí a jednáním, tj. nevynucené vnitřní jednoty lidské osoby se sebou samou. Etika vzdoruje každému pokusu vysvětlit skutečnost výhradně z hlediska její funkčnosti a ovladatelnosti, z hlediska všezahrnujících modelů teoretického poznání nebo zástupného „šermování s Bohem“ a nemilosrdně odhaluje jakékoliv narušení naší osobní i kolektivně-institucionální věrohodnosti. I jedinec, který je v určitých projevech zručnosti nebo ducha oslavován jako „neprůstřelný guru“, se pod ostrým pohledem svědomí může snadno projevit jako totální amatér „V umění být“, který svou vnitřní rozpolceností podkopává důvěru ostatních v možnost žít svůj život (navzdory všem nedokonalostem) jako spojitý př́běh. Etika tak umožňuje vždy znovu objevovat zasutou výzvu naší osobní i kolektivní identity a integrity. ${ }^{5}$

Pokud jde o samotnou otázku etiky hospodářství, každý pokus o nalezení jejího východiska se bude vždy potýkat se dvěma krajnostmi: s odtržením ekonomiky a morálky jako dvou zcela nesouvisejících oblastí a s jejich prímým ztotožněním nebo odvozením. První krajnost souvisí s nastolením historické převahy technokratického vědomí v každodenní kultuře západní civilizace, kterou v našem kontextu dobře vystihuje výrok dvou představitelů tzv. „teorie her“, že metoda ekonomie je vždy stejná, „at ji /používá/ Attila náčelník Hunů nebo svatý František“. ${ }^{\circ}$ Druhá krajnost vytvárí paradoxní pouto mezi anarcholibertariány, kteří ničím nepodmíněnou možnost volby a hledání libovolně definovaného vlastního prospěchu chápou jako automatické řešení všech hospodářsko-etických problémů, a levicovými kritiky volného trhu, podle nichž může být současný kapitalismus „mravně zachráněn“ jen tehdy, bude-li „mocensky vykleštěn“ nebo zničen. ${ }^{7}$ Naším předběžným východiskem bude, že ačkoliv tržní ekonomika a etika musejí hovořit každá ze svého vlastního místa, jsou společně zakotveny v lidském bytí a jednání jako takovém. Jedině z této původní a zároveň dějinně otevřené jednoty hospodářství a lidskosti (kterou lze ovšem zachytit jen jako jednotu $\mathrm{v}$ křehkosti, nejednoznačnosti a paradoxu) lze vyčíst smysl hospodářsko-etického myšlení v naší každodenní žité zkušenosti.

\section{Tři dimenze vztahu mezi morálkou a ekonomikou}

Překlenutí zdánlivé propasti mezi „faktickým chodem“ a mravním chápáním tržního hospodářství je podle mnoha současných interpretů klíčem k nalezení východiska hospodářské etiky. ${ }^{8}$ Tento požadavek však nesmí zůstat pouhou formální proklamací, ale musí také popsat konkrétní způsoby svého uskutečnění. Prvním vodítkem na cestě k tomuto cíli může být hermeneutický

4 Srov. úvahy filosofa Michaela Polányiho prezentované v knize: Jaroslav VOKOUN, Postkritický proud v současné angloamerické teologii, Praha: Vyšehrad, 2009, s. 26 a 46.

5 Zvláštností etického vědění je podle hermeneutického filosofa Hanse Georga Gadamera to, že mu vždy jde o „správnost života jako celku“, že nikdy nedisponuje předem hotovými vědomostmi ani dokonalým určením vlastních cílů, a přesto musí převzít odpovědnost za křehké provizorium momentálního lidského rozhodnutí. Srov. Hans Georg GADAMER, Problém dějinného vědomí, Praha: Filosofia, 1994, s. 37-38.

6 Ken BINMORE - Avner SHAKED, Experimental economics: Where next?, Journal of Economic Behavior \& Organization 73/2010, s. 98 (on-line), dostupné na: http://www.wiwi.uni-bonn.de/shaked/papers/Binmore-shaked-WhatNext.pdf, citováno dne 3. 12.2016.

7 Pro př́klad prvního postoje viz rozhovor s „anarchokapitalistou“ Murray Rothbardem pro časopis The New Banner v roce 1972, (c) The New Banner (on-line), dostupné na: http://archive.lewrockwell.com/rothbard/rothbard103.html, citováno dne 27. 7. 2016. Pro př́pad druhého viz Slavoj ŽIŽEK, Požadujme nemožné, Praha: Rybka Publishers, 2011; Geert van ISTENDAEL, Farnost sv. Prekéra: Hospodářská a ekonomická krize - př́činy, souvislosti, di̊sledky, Praha: Nakladatelství Lidové noviny, 2014.

8 Viz např. sborníky: Peter SCHALLENBERG - Arnd KÜPPERS (ed.), Interdisziplinarität der Christlichen Sozialethik, Paderborn: Ferdinand Schöningh, 2013; Detlef AUFDERHEIDE - Martin DABROWSKI (ed.), Markt und Verantwortung: Wirtschaftsethische und moralökonomische Perspektiven, Berlin: Duncker \& Humblot, 2015. 
popis dynamiky vzájemných vazeb mezi morálkou a tržní ekonomikou, která se promítá v naší typické každodenní lidské zkušenosti a má podobu „jednoty v napětí“ tří neustále působících momentů: 1. momentu symbiózy, 2. momentu sváru a 3. momentu transcendence.

První moment vzdoruje redukci ekonomiky na vnější mechanismus maximalizace zisku i absolutizaci morálky, která všechny hospodářské úvahy odvozuje z předem kategoricky daných mravních imperativů, a poukazuje $\mathrm{k}$ hlubokému vzájemnému prostupování morálky a hospodářství v naší každodenní praxi. Ukazuje, jak i ve zdánlivě nejodcizenějším hospodářském provozu jsou př́tomna potlačená dilemata svědomí a jak i nejnáročnější etické ideály vyžadují efektivní zhodnocení našich sil, př́ležitostí a nákladů pro jejich uskutečnění. $S$ touto úvahou jde ruku v ruce potřeba neustálého a souběžného prohlubování etické reflexe hospodářských jevů a věcné znalosti fungování tržní ekonomiky. Hospodaření a mravnost se sbližují na cestě za stále plnější výkonností a odpovědností, a vtiskují hospodářské etice nejen poslání průvodce $\mathrm{k}$ dobru, ale $\mathrm{i}$ strategického rádce, jak ho prakticky dosáhnout. Konkrétním př́kladem této symbiózy mohou být nejrůznější etické kodexy a audity, dobročinnost firem nebo jejich spolupráce s neziskovým sektorem.

$\mathrm{V}$ druhém momentu se schopnost etiky bezprostředně a účinně působit na hospodářskou činnost ukazuje jako omezená, a stejně tak i schopnost ekonomiky zvládat temné a lidsky destruktivní síly, které je schopna uvolnit. Jednat morálně zde znamená do jisté míry z ekonomiky vystoupit, jednat ekonomicky znamená mravně se zkompromitovat. Aby mohla zůstat morálka morálkou a ekonomika ekonomikou, musí se vzájemně postavit na odpor, aniž by se přitom zřekly společného úkolu překonávat lidskou částečnost.

V třetím momentu se etika a ekonomika opět setkávají, ovšem na rovině upřímného uznání vlastní omezenosti a krize; krize ekonomiky, která se jednostranností své „racionality“ může snadno stát iracionální, a krize etiky, která se strnulostí svého moralizování činí bezmocnou řešit skutečné problémy hospodářsky činných i hospodářsky trpících lidí. Ekonomie si například musí přiznat svou dlouhodobou neschopnost unést vratkost hospodářského života, zejména neodstranitelný fakt lidské smrtelnosti. Někteří ekonomičtí antropologové se domnívají, že právě tento deficit zakrývaný zkratovitými způsoby překonávání nejistot je jednou z hlavních příčin selhávání tržně-hospodářských systémů, jichž jsme dnes svědky. ${ }^{9}$ Samotná ekonomie může jen stěží vysvětlit nahodilosti, které vedou $\mathrm{k}$ hospodářskému úspěchu a neúspěchu, nebo nabídnout univerzální recept, jak se v životě zaměřeném na pouhé stupňování blahobytu vyrovnat s celkovou osobní $\mathrm{i}$ kolektivní krizí smyslu. Ani etika však dosud nedokázala uspokojivě objasnit řadu běžných forem každodenního hospodářského utrpení a obecně pak otázku, proč se právě v hospodářském životě necháváme tak snadno pokřivit, zkazit a odcizit a proč právě zde jsou mnozí čestní a podnikaví lidé tak snadno ponižováni a vylučováni na okraj.

Je ale etická i technokratická bezmocnost pouze negativním jevem, který je třeba okamžitě překonat novým náporem výkonnosti a ideálů (popř́padě ideologií), nebo je také šancí nahlédnout meze naší schopnosti pouze spotřebovávat a hodnotit svět, a otevř́t tak nové možnosti, jak ho také společně chránit, sdílet a rozvíjet? Nevzniká skutečná hospodářská etika až v mezních situacích, $\mathrm{v}$ nichž musíme dát vlastní pojetí dobrého života $\mathrm{v}$ sázku a riskovat, že bude „odměněno“ také hospodářským krachem a nejistotou? A nedospíváme $\mathrm{k}$ dlouhodobě udržitelné prosperitě

9 Srov. výklad v knize John CASSIDY, Jak selhávají trhy, s. 206-207. 
až ve chvíli, kdy zisk pro nás není jediným ani posledním cílem života? Zkoumání hospodářské moci „hospodářsky bezmocných“ a hospodářské morálky zdánlivě „hospodářsky nemravných“ (např. reklamních agentů nebo burzovních makléřů) uvolňuje ekonomii i etiku od jejich nutkavých metodických redukcí a otevírá vzrušující pole nových badatelsky i prakticky přínosných poznatků.

V každém př́ípadě platí, že všechny pokusy úplně z ekonomiky odstranit otázku po dobrém životě končí zpravidla planou utopií nebo destruktivní tyranií. I v nejsložitějších bludištích hospodářských systémů a v nejpudovějších smyčkách spotřebitelských rutin se vždy projevuje velikost, křehkost a konečnost našeho lidství, s nímž je třeba vždy počítat a zároveň mu odpovědně čelit. Může $\mathrm{k}$ tomu nějak přispět také svobodymilovné a hospodářsky vnímavé křestanství?

\section{Př́nos křest’anské etiky pro etiku hospodářství?}

Druhým klíčovým tématem této studie je popsat a zdůvodnit možný př́nos křestanské a zejména katolické etiky pro současnou etiku tržního hospodářství. Co nového a skutečně zvláštního do ní vnáší život $\mathrm{z}$ víry $\mathrm{v}$ jeho Bohem darovaných i lidsky autonomních podobách? Ve shodě s hlavní linií své tradice katolická etika jistě neničí vše přirozené a pravdivé, oč v hospodářské oblasti usilují lidé dobré vůle, a také její vlastní poselství je prostoupeno univerzálním úsilím o lidskost. Přesto je třeba zamyslet se nad tím, co může být křestanům v hospodářské sféře vlastní a oč se v dialogu s dalšími aktéry mohou podělit.

Křestanství je pro tržní hospodářství výzvou od jeho historických počátků. A to zdaleka ne jen ve smyslu kalvínské etiky prosperity jako Boží př́izně popsané německým sociologem Maxem Weberem v jeho klasickém díle Protestantská etika a duch kapitalismu. ${ }^{10}$ Podle některých současných historiků a hospodářských antropologů vznikají už v tradičních řeholních komunitách, zvláště v žebravých řádech italského pozdního stř̌edověku (u františkánů a minoritů), první zárodky racionální tržně-hospodářské praxe, ovšem zasazené do širšího úsilí o křestanskou solidaritu, pokoj a společné dobro. ${ }^{11} \mathrm{Na}$ institucionální rovině se tyto snahy projevily zakládáním nelichvářských křestanských záložen, tzv. Montes pietatis, v nichž se snoubil duch křestanské charity s požadavkem její dlouhodobé hospodářské udržitelnosti. ${ }^{12} \mathrm{~V}$ renesanci a raném novověku se křestanská společnost postupně smiřuje s mravní legitimitou úsilí o zisk, které bylo s odkazem na některé pasáže evangelia původně spíše odsuzováno, a začleňuje ho do vlastního poselství spásy a služby. ${ }^{13}$

Nástup moderní průmyslové revoluce situaci definitivně obrací, tržní hospodářství se prosazuje $\mathrm{v}$ celospolečenském měrítku a křestanství hrozí, že nebude schopno čelit novým mravním a sociálním problémům, které z tohoto vývoje vyplynuly (odlidštění pracovního prostředí, kruté zacházení s dělníky apod.). Odpovědí na novou situaci masové industrializace, neregulovaného podnikání a námezdní práce je dílo raných osobností katolického sociálního hnutí a později

10 Max WEBER, Protestantská etika a duch kapitalismu, in: Metodologie, sociologie a politika, Max WEBER, Praha: OIKOYMENH, 2009, s. 182-223.

11 Srov. Peter SCHALLENBERG, Franziskus, Anstöße zu einer franziskanischen Soziallehre, Köln: Bachem, 2013, s. 13.

12 Srov. Luigino BRUNI - Stefano ZAMAGNI, Zivilökonomie: Effizienz, Gerechtigkeit, Gemeinwohl, Paderborn: Ferdinand Schöningh, 2013, s. 62.

13 K této zajímavé historické otázce viz zejména Pavel BLAŽEK, Tři dopisy Tomáše Akvinského, Praha: Krystal, 2010. Srov. dále Jacques LE GOFF, Peníze ve středověku: Historicko-antropologická studie, Praha: Mladá fronta, 2010, s. 163; Bartolomé CLAVERO, Antropológia Católica de la Economía Moderna, Milano: Giuffrè, 1991. 
sociální nauka církve. Stejně naléhavou výzvou pro křestanskou sociální etiku je však i současný proces hospodářské globalizace popsaný papežem Benediktem XVI. jako „exploze vzájemné celoplanetární závislosti“, kterému chce církev čelit solidaritou, důslednou obranou lidských práv, univerzálním zpřístupněním techniky a znalostí, uvolněním mezinárodního obchodu, rozvojovými programy, mezigenerační ochranou životního prostředí a především duchovní obnovou svědomí každého člověka. ${ }^{14}$

Naším úkolem nyní bude ukázat, jak se tyto výzvy tradice i zmíněné tři momenty „přirozené vazby“ mezi etikou a ekonomií projevují v různých myšlenkových proudech současné katolické etiky tržního hospodářství. Pojem katolické etiky zde neoznačuje denominační výlučnost, nýbrž ne-mocenskou univerzalitu nároku číst konkrétní dějinnou zkušenost s tržním hospodářstvím z pohledu křehké celistvosti našeho vykoupeného lidství a dynamické provázanosti katolického sociálního učení, myšlení a praxe. ${ }^{15}$ Teologickým jádrem této etiky je obnova každého člověka a celého lidstva přijetím spoluúčasti na dokonalé jednotě v rozličnosti osob Nejsvětější Trojice založené na svobodném sebedarování. ${ }^{16}$

Náš výklad si s ohledem na členitost současné debaty neklade nárok na úplnost; snaží se však přesto vystihnout hlavní současné př́istupy katolické hospodářské etiky, zejména $\mathrm{v}$ americké a německé oblasti. Tyto př́stupy jsme schematicky rozdělili do šesti skupin: 1. Ekonomika daru; 2. „Evangelium prosperity“ (protržní pojetí); 3. Sociální reformismus a sociálně-tržní hospodářství; 4. Kritický realismus a spoluodpovědnost za vzdálené tržní škody; 5. Mikroetika firemního života; 6. Alternativní pohledy. U každého z těchto př́istupů nastíníme jeho základní přínos pro debatu o smyslu etiky tržního hospodářství a naznačíme, jak mohou přispět k překlenutí propasti mezi ekonomikou a morálkou, popř. hospodářskou spiritualitou.

\subsection{Ekonomika daru}

Prvním a pravděpodobně nejvlivnějším směrem současného katolického hospodářského myšlení je tzv. ekonomika daru. Tento směr má hluboké kořeny v křestanské teologické tradici výkladu veškeré skutečnosti a lidského bytí jako Božího daru a současně se protíná s úvahami hospodářské antropologie a filosofie poukazující k souvislosti směny, moci a daru v dějinách ekonomiky. ${ }^{17}$ V nejhutnější podobě je základní koncept ekonomiky daru vyjádřen papežem Benediktem XVI. v článku 34 encykliky Caritas in veritate z roku 2009. Zkušenost daru je poukazem k iluzornosti přesvědčení, že člověk je jediným a absolutním původcem svých hospodářských jistot, a může proto žít jen z pocitu vlastní soběstačnosti a zásluh. Křest’anská etika ukazuje, že u kořene každého hospodářského rozvoje je kromě spravedlnosti, důvěry, obecného dobra nebo uznání každé osoby také určitá logika nezištnosti, která pomáhá i ekonomické vztahy přetvářet ve vztahy

14 BENEDIKT XVI., Caritas in veritate, Kostelní Vydř́i: Karmelitánské nakladatelství, 2009, čl. 33. Dále v textu pouze CV a číslo př́íslušného oddílu. Popis různých forem solidarity v globalizované ekonomice nacházíme především v článcích 363-367 Kompendia sociální nauky církve. Viz PAPEŽSKÁ RADA PRO SPRAVEDLNOST A MÍR, Kompendium sociální nauky církve, Kostelní Vydří: Karmelitánské nakladatelství, 2008, čl. 363-367. Dále v textu pouze KSNC a číslo př́slušného oddílu.

15 KSNC 38.

16 KSNC 34. Srov. Ctirad Václav POSPÍŠIL, Jako v nebi, tak i na zemi: Náčrt trinitární teologie, Praha: Krystal OP, Kostelní Vydř́í: Karmelitánské nakladatelství, 2007, s. 70-71.

17 KSNC 20. Srov. Karl POLÁNYI, Velká transformace, Brno: CDK, 2006; Jacques LE GOFF, Peníze ve středověku; Marcel MAUSS, Esej o daru, podobě a di̊vodech smèny v archaických společnostech, Praha: SLON, 1999; @ Santa Clara University Information Technology Department, Retrieving Franciscan Philosophy for Social Engagement (on-line), dostupné na: http://webpages.scu.edu/ftp/kwarner/ Fran-WarnerRetrievingFranciscanPhilosophy.pdf, citováno dne 19. 7. 2016. 
bratrství. ${ }^{18} \mathrm{Na}$ praktické rovině z toho encyklika vyvozuje zejména posílení hospodářské role „občanské společnosti“ " chápané jako členitá oblast zprostředkování mezi soukromým a veřejným sektorem a prolínání soukromých podniků usilujících o zisk s organizacemi usilujícími o „lidské a sociální cíle“. Uskutečnění této vize by mohlo přispět k celkové „humanizaci ekonomiky“. ${ }^{19}$

Toto pojetí označené v čl. 46 také jako „občanská ekonomika“ nebo „ekonomika společenstvi“ navazuje na stejnojmennou koncepci dvou italských teologů a etiků Stefana Zamagniho a Luigina Bruniho shrnutou v jejich společné knize Economia civile z roku $2004 .{ }^{20} \mathrm{Na}$ podkladě hospodářského modelu „civilního humanismu“ $\mathrm{v}$ italských františkánských komunitách pozdního středověku popsaných historikem Giacomem Todeschinim rozvíjejí tito autoři pojetí ekonomiky založené na nezištné lidské vzájemnosti (reciprocitě) a hledají způsoby jeho propojení s běžným úsilím o blahobyt a smluvní rovnocenností.

Ekonomika daru je př́nosná svým připomenutím historické jednostrannosti pohledu na moderní tržní ekonomiku jako na pouhou sféru směny a maximalizace zisku a svým zakotvením hospodářské činnosti v síti boholidské vzájemnosti a mezilidské vděčnosti. Jejím úskalím je nedostatečná reflexe nedokonalosti lidského daru ve srovnání s darem Božím a jeho ambivalentnosti v konkrétním dějinném, právním a politickém kontextu (např. vztahu daru a dluhu, daru a spravedlnosti, daru a finanční odpovědnosti apod.). Proto se někteří autoři pokoušejí ekonomii daru propojovat s dalšími prvky, např. s důvěrou, nepředvídatelností svobodného jednání nebo se zvažováním proporce mezi nezištností a hospodářskou prosperitou. ${ }^{21}$

\section{2 „Evangelium prosperity“ (protržní pojetí)}

Katolickou protržní ekonomii svobody a hospodářské prosperity reprezentují především úvahy amerického teologa slovenského původu Michaela Novaka a jeho kolegů z okruhu tzv. Acton institutu v USA (např. Roberta Siricoea, George Weigela aj.). Širší paletu názorů vycházejících $\mathrm{z}$ této pozice nabízí např. sborník Catholic Social Teaching and the Market Economy vydaný Institutem pro ekonomické záležitosti v Londýně krátce před světovou hospodářskou krizí (2007). ${ }^{22}$ Člověk v pojetí katolických libertariánů je tvořivou racionální bytostí nepřekonatelně zasaženou hř́chem a jeho snahu o uspokojení vlastního zájmu na maximálně deregulovaném trhu je třeba považovat za mravně legitimní. Každá snaha politicky regulovat ekonomiku podvazuje lidskou tvořivost a může vést ke vzniku politických tyranií založených na utopické vizi člověka. I katolík musí být maximálně ostražitý vůči jakémukoliv (zejména mocensky prosazovanému) absolutnímu nároku dobra a spravedlnosti v ekonomice, vůči náhradě mzdy pouhými sociálními dávkami,

18 CV 34, 37, 38 a 39. Viz dále rozvinutí těchto motivů ve sborníku Daniel K. FINN (ed.), The Moral Dynamics of Economic Life: An Extension and Critique of Caritas in veritate, Oxford: Oxford University Press, 2012.

19 CV 38, 46.

20 Luigino BRUNI - Stefano ZAMAGNI, Economia civile: Efficienza, equità pubblica, Bologna: Il Mulino, 2004.

21 Srov. především Simona BERETTA, Wealth Creation in the Global Economy: Human Labor and Development, in: Rediscovering Abundance. Interdisciplinary Essays on Wealth, Income, and Their Distribution in the Catholic Social Tradition, ed. Helen ALFORD - Charles M. A. CLARK - Steve A. CORTRIGHT - Michael J. NAUGHTON, Notre Dame: University of Notre Dame Press, 2006 s. 129-156; Marco BONACKER, Wirtschaftsethik mit theologischem Hintergrund: Interdisciplinäre Notwendigkeit als Chance, in: Interdisziplinarität der Christlichen Sozialethik, ed. Peter SCHALLENBERG - Arnd KÜPPERS, s. 100-104. K otázce hledání proporce mezi ziskem a trvalou udržitelností v ekonomice srov. např. Anselm GRÜN - Jochen ZEITS, Bůh a peníze: Dialog mnicha s manažerem, Kostelní Vydří: Karmelitánské nakladatelství, 2013, s. 29-30.

22 Philip BOOTH (ed.), Catholic Social Teaching and the Market Economy, London: The Institute of Economic Affairs, 2007. K systematickému výkladu Novakovy teologie hospodářství srov. zejména Roman MíčKA, Michael Novak a jeho projekt teologie demokratického kapitalismu, Brno: Luboš Marek, 2009. 
podnikání chudých pouhým přerozdělováním hospodářské pomoci nebo dobrovolné solidarity daňovou povinností. Svobodný trh je pro katolické libertariány jedinou eticky oprávněnou institucí schopnou rozvinout lidskou svobodu, kreativitu a prosperitu. ${ }^{23}$

Hlavní předností katolického libertarianismu je jeho důraz na praktickou prozíravost v hospodářském životě, schopnost čelit některým nerealistickým utopiím a otupit v minulosti vyhrocenou polemiku katolické sociální tradice s ústavně demokratickým zřízením. Cenná je také jeho vnímavost k pozitivním stránkám „kapitalistické“ globalizace a odpor k naivním nostalgiím po stavovské ekonomice předmoderní doby. Problémem je však zlehčování destruktivních vedlejších účinků volného trhu v oblasti finanční stability, veřejných statků, kultury, vzdělání, životního prostředí nebo rodinných vztahů. Katoličtí libertariáni často přeceňují význam dobrovolné morálky a neformálních dohod mezi podnikateli a přehlížejí nutnost institucionálního prosazování obecných tržních pravidel, typicky v oblasti mezinárodních investic nebo spekulací na finančních trzích. Eticky diskutabilní je také jejich zacházení s lidským hříchem jako veličinou, s níž musí tržní systém vždy počítat a někdy na ní v jistém smyslu i „stavět“. ${ }^{24}$ Sociální nauka církve však opakovaně upozorňuje, že hřích je brzdou, nikoliv motorem hospodářské prosperity a rozvoje, a že hřích hospodářských struktur se nakonec obrací i proti osobní svobodě, kterou měl zdánlivě zajištovat. Naproti tomu umírněná, ale v pečlivě vymezené oblasti zároveň důsledná regulace tržních procesů může být v zájmu stability trhu, jak se stalo patrným po globální hospodářské krizi roku $2008 .^{25}$

Z důvodu dogmatického lpění některých katolických libertariánů na představě tržní samoregulace se vyplatí naslouchat také umírněnějším hlasům $z$ téhož tábora. Přestože americký dominikánský ekonom Albino Barrera věnoval většinu svých prací mnohostranné obhajobě volného trhu jako nejúčinnějšího nástroje rozdělování statků a ekonomické globalizace jako podnětu $\mathrm{k}$ „rozšíření mravních závazků a odpovědnosti“ v celosvětovém měřítku, dokáže být kritický k absolutní glorifikaci trhu jako systému dokonalé předvídatelnosti, racionality a svobody a uznat také nezamýšlené vedlejší škody (externality), které trh přirozeně působí některým zranitelným společenským skupinám. ${ }^{26}$ Ve své knize Market Complicity and Christian Ethics z roku 2011 Barrera rozlišuje čtyři typy těchto škod; dva lze přímo spojit s lidskou odpovědností a spoluvinou (uschopnění k špatnému jednání a urychlené vyvolání nadbytečných škod) a dva jen nepřímo odrážejí nevyhnutelný dopad kumulativních škod (přehlížení vnějších dopadů vlastního hospodářského jednání, posilování nespravedlivých socioekonomických praktik nebo institucí). ${ }^{27}$

\subsection{Katolický sociální reformismus a pozice sociálně-tržního hospodářství}

Dalším vlivným směrem katolického hospodářského myšlení je pozice zastánců tzv. sociálně-tržního hospodářství pocházejících především z německé tradice. Někdy se v této souvislosti hovoří

23 Philip BOOTH, Catholic Social Teaching, s. 35-37.

24 Srov. Michael NOVAK, A Closet Capitalist Confesses, in: Three in One. Essays on Democratic Capitalism 1976-2000, ed. Edward W. YOUNKINS, Lanham: Maryland, Rowman \& Littlefield Publishers Inc., 2001, s. 6-12. Viz dále Michael NOVAK, Challenges to Benedict's Vision. Sin, in: The Moral Dynamics of Economic Life: An Extension and Critique of Caritas in veritate, s. 33-36.

25 Srov. Wolf-Gero REICHERT, Unternehmen unter der Dominanz der Finanzmärkte?: Orientierungen aus Sozialethischer Perspektive, AUC Theologica 1/2016, s. 100-102.

26 Srov. Albino BARRERA, Individuating Collective Responsibility, in: Distant Markets, Distant Harms: Economic Complicity \& Christian Ethics, ed. Daniel K. FINN, Oxford: Oxford University Press, 2014, s. 230-231. Barrera tvrdí, že zmíněné negativní vnější dopady tržních procesů jsou pouze nepř́mým důsledkem pohybu cen a oběhu peněz v globální tržní ekonomice (označuje je proto termínem „peněžní externality“, pecuniary externalities). Srov. tamtéž.

27 Albino BARRERA, Market Complicity and Christian Ethics, Cambridge: Cambridge University Press, 2011. 
o katolickém reformismu nebo o tzv. höffnerovské škole (podle významného badatele $\mathrm{v}$ oblasti sociální etiky kardinála Josefa Höffnera, 1906-1987). Tento proud má kromě svých tomistických kořenů blízko i $\mathrm{k}$ tzv. německému ordoliberalismu a $\mathrm{k}$ některým ideálům spojeným se vznikem Evropské unie. Ve starší tradici je třeba rozlišovat proud čistě ordo-liberální (Walter Eucken a jeho žáci), podle něhož je volný trh „již sociální“ sám o sobě, protože zvyšuje univerzální šance na rozvoj, a proud „sociálně-politický", který požaduje aktivnější usměrňování trhu k žádoucím společenským cílům (Wilhelm Röpke, Alexander Rüstow, Alfred Müller-Armack). ${ }^{28}$ Náš výklad se v zájmu přehlednosti zaměří na pojetí kardinála Reinharda Marxe, který je spiše zastáncem druhého ze zmiňovaných proudů a v českém prostředí je známý především knihou Kapitál: Plaidoyer pro člověka $\mathrm{z}$ roku $2008 .^{29}$

V publicisticky vděčném úvodu této knihy se kardinál Marx na jedné straně hlasí k tradiční von Kettelerově sociálně-reformní vizi uspořádání tržního hospodářství, která chtěla nasměrovat užívání soukromého vlastnictví ke společnému dobru a řešit třídní rozpory mezi dělníky a zaměstnavateli smírným kolektivním vyjednáváním, na druhé straně si však klade otázku, zda také některá diagnostická varování marxistů nezískala novou aktuálnost v souvislosti se současnou ekonomickou globalizací. ${ }^{30}$ Výčet závažných rizik spojených s tímto procesem podle Reinharda Marxe zahrnuje: snižování daní velkých podniků a nárůst odvodů běžných občanů, všeobecnou nejistotu zaměstnání (tzv. prekariát), odstraňování tarifního mzdového systému, snižování pracovněprávní ochrany a důchodového zabezpečení, oslabování pozice odborů vůči nadnárodním korporacím, prohloubení propasti mezi bohatými a chudými, dětskou chudobu, neomezené finanční spekulace na účet daňových poplatníkủ, postupný rozklad střední třídy, vyostřenou konkurenci zaměstnanců a investičních lokalit, tlak investičních fondů na krátkodobé zisky na úkor tržní stability, jednostrannou zájmovou politiku mezinárodních finančních institucí apod. ${ }^{31}$

Receptem na tyto problémy je podle Marxe model „globálního sociálně-tržního hospodářství, který by ekonomiku zakotvil v celosvětovém politickém řádu „orientovaném na obecné blaho a poskytujícím prostor pro institucionalizovanou solidaritu“. ${ }^{32}$ Jednalo by se o rozšíření tzv. sociálního státu na globální úroveň a současně o jeho transformaci do flexibilnějšího modelu, který by sice umožnil vyrovnávat třídní protiklady a chránit před globálním růstem tržního rizika, ale jen natolik, aby byli jednotlivci schopni se sami aktivizovat a starat se o věci soukromé i veřejné (Marx v návaznosti na Alexandera Rüstowa hovoří o „vitální politice“). ${ }^{33}$ Hodnotovým jádrem Marxovy hospodářské etiky je lidská svoboda, ovšem svoboda mnohonásobně podmíněná uskutečňováním pravdy skrze společné dobro, osobní důstojností a „sociálním vyrovnáním“, zárukou svobody pro všechny, obecně závaznými pravidly a ústavně-demokratickou státní autoritou. ${ }^{34}$ Druhou její klíčovou hodnotou je sociální spravedlnost chápaná nejen jako předpoklad osobních svobod a materiálního zajištění, ale také všeobecné účasti všech občanů na základních úkonech

28 Srov. Gerhard KRUIP, Tržní hospodářství v katolickém sociálním učení, AUC Theologica 1/2016, s. 28. Paleta křestanských přístupů k hospodářské etice v německém okruhu je však daleko rozmanitější, jak naznačuje např. již zmíněný sborník Detlef AUFDERHEIDE

- Martin DABROWSKI (ed.), Markt und Verantwortung. Wirtschaftsethische und moralökonomische Perspektiven; nebo opět Gerhard Kruip v článku Gerhard KRUIP, Aktuelle sozialethische Beiträge zu Wirtschaftsethik und Unternehmensethik, Jahrbuch für Christliche Sozialwissenschaften 51/2010, s. 321-350.

29 Reinhard MARX, Kapitál. Plaidoyer pro člověka, Praha: Academia, 2013.

30 Srov. tamtéž, s. 24 n.

31 Srov. tamtéž, s. 25-27.

32 Tamtéž, s. 198.

33 Srov. tamtéž, s. 199-200.

34 Srov. tamtéž, s. 64-65. 
života společnosti. ${ }^{35}$ Trh sám není v sociálním hospodářství cílem, nýbrž pouhým nástrojem $\mathrm{k}$ „trvalému a zajištěnému utváření materiálních předpokladů, které jednotlivci i sociálním útvarům umožňují lidsky důstojný rozvoj". ${ }^{36}$

V návaznosti na sociálně orientovaný proud německého ordoliberalismu navrhuje Reinhard Marx řadu praktických reforem, které podle něj odpovídají výzvám tržního hospodářství v 21. století. Jsou to např. obnova tarifních mzdových vyjednávání na celosvětové úrovni (globální obdoba tripartity), etické audity, ručení manažerů za škody osobním majetkem, účinnější regulace „supích fondü“ a finančních spekulací, odstraňování extrémní chudoby rozvojovými programy (založenými na dlouhodobé „pomoci ke svépomoci“ i přímém přerozdělování nejchudším), otevření trhů rozvojovým zemím i ekologická péče v zemích rozvinutých, osobní setkávání bohatých s chudými, pomoc chudým zemím s vybudováním správy a infrastruktury, bojkot sociálně neodpovědných výrobců, vytvoření tzv. „třetího trhu práce“, ustavení globální politicko-hospodářské autority nastolující spravedlivou soutěž a všeobecnou spoluúčast. ${ }^{37}$

Sociálně-tržní etika hospodářství je prospěšná svou diagnózou konfliktních momentů trhu a etiky a kritickou analýzou hrozeb hospodářské globalizace. Je však místy př́liš rovnostářská a nebere dostatečně v potaz otázku hospodářské efektivity ani komplexní povahu současných hospodářských nespravedlností. „Odcizeni““ člověka $\mathrm{v}$ dnešním světě totiž nepochází pouze z nadměrné tržní deregulace, nýbrž také ze souběžně zbytňujících a občansky neúčinně kontrolovaných struktur politické moci a násilí.

\subsection{Kritičtí realisté a spoluodpovědnost za vzdálené tržní škody}

Současná škola tzv. katolických kritických realistů, převážně badatelů amerického a italského původu (např. Daniel K. Finn, Douglas V. Porpora, Margaret Archer, Pierpaolo Donati aj.), se zabývá především zvláštní proměnou mezilidských vztahů v kontextu hospodářské globalizace. $\mathrm{V}$ důsledku propojení trhů, technologií a politicko-právních institucí se v současné ekonomice rozšiřuje okruh sociálních vztahů založených na neosobním odstupu mezi lidmi, vztahů nepř́ímých nebo převážně zprostředkovaných pravidly a institucemi. Tento typ vztahů znásobuje tržní závislosti a dopady našeho jednání na tzv. „vzdálené bližní“, čímž vyvolává otázku po rozsahu naší mravní spoluodpovědnosti za tzv. vzdálené tržní škody. ${ }^{38}$ Samotný pojem „kritičtí realisté je označením sociologického zaměření této skupiny na zkoumání komplexnosti prríčin společenského jednání vyjádřené pojmem „emergence“. Emergence je zvláštním vztahem dvou prvků (v našem případě hospodářských aktérů), který svým „kauzálním dopadem“ umožňuje vznik zcela nové skutečnosti, na rovině jednotlivých prvků neexistující. Tato skutečnost nám ztěžuje odhalení souvislosti mezi vlastním jednáním a naším působením na vzdálené bližní, a tím také posouzení míry naší spoluodpovědnosti za globální hospodářská rozhodnutí. ${ }^{39}$

35 Srov. tamtéž, s. 65.

36 Joseph HÖFFNER, Christliche Gesellschaftslehre, Kevelaer: Lothar Roos, 1997, s. 75.

37 Srov. Reinhard MARX, Kapitál, s. 181-182.

38 Zřejmě nejucelenějším odborným textem na toto téma formulovaným z pozice kritických realistů je již uvedený sborník Daniel K. FINN (ed.), Distant Markets, Distant Harms z roku 2014.

39 Srov. Pierpaolo DONATI, The Morality of Action, Reflexivity and the Relational Subject, in: tamtéž, s. 58-73; Douglas V. PORPORA, Who is Responsible? Critical Realism, Market Harms, and Collective Responsibility, in: tamtéž, s. 4-21. Tyto úvahy mají také přinejmenším nepřímou souvislost s katolickým učením o tzv. hříchu struktur. 
Kritičtí realisté $\mathrm{v}$ této souvislosti hovoří o systémově-strukturální zakotvenosti svobody volby, která sice komplikuje, ale neruší lidskou odpovědnost. Naše odpovědnost je jen stále více svázána s jevem, který lze označit jako „sítový efekt“. Jednotlivec vstupuje na trhu nejprve do jakési prvotní „sítě blízkosti“, dynamikou svých vztahů však nepřímo působí i vně této sítě a jeho mravní odpovědnost je přímo úměrná jeho postavení a rozhodovacímu vlivu v rámci této sítě. Př́íladem může být jednání burzovního makléře, který sice není odpovědný za veškeré spekulace prováděné na finančních trzích, ale přesto musí v užším dosahu svých tržních transakcí ze svého jednání vydávat počet. ${ }^{40}$

Klíčovou otázkou nyní je, zda se kritičtí realisté, v oprávněné snaze vymezit hranice naší odpovědnosti za hospodářské škody vůči „vzdáleným bližním“, mohou spokojit pouze s abstraktně vědeckými (a zkušenostně nepř́liš vykazatelnými) pojmy kauzálního dopadu nebo sítového efektu a zda by neměli nejprve filosoficky objasnit souvislost mezi lidskou svobodou a lidskou vztahovostí na pozadí našeho vztahu ke světu a dějinám jako celku. Jsou vztahy ke „,zdáleným bližním“ jen vnějším rysem objektivisticky pojímané reality, nebo mají nějaký vztah ke každodennímu vnímání naší zdánlivé bezmocnosti a neosobnosti tváří v tvář dnešním problémům globální ekonomiky? A je možné je přes jejich zbytnělou moc a rutinní chod stále chápat jako „zprostředkovanou“ dimenzi naší bezprostřední žité zkušenosti? Kromě tohoto filosofického deficitu musí kritičtí realisté čelit také námitce, která má více etickou povahu. Již zmíněný umírněný hospodářský teolog Albino Barrera se ve svém článku Individuating Collective Responsibility právem ptá, zda př́liš vágně kolektivisticky pojatá odpovědnost za tržní škody nemůže vést $\mathrm{k}$ tomu, že za ně nakonec nepřevezme odpovědnost nikdo a že nikdo také nebude schopen dovést jejich nápravu ke konkrétní realizaci. Je třeba se také ptát, zda není pro posouzení hospodářské odpovědnosti konkrétních osob potřeba stanovit i jiná kritéria než je př́slušnost $\mathrm{k}$ „vztahové síti“ společenského jednání, např. mentální schopnost aktérů, mravní přesvědčení, okruh lidí, na které tato škoda dopadla, apod. ${ }^{41}$

\subsection{Mikroetika firemního života}

Pozornost katolických hospodářských etiků však není upřena pouze na oblast „velké ekonomiky“ a globálních tržních vztahů, ale také na etické problémy konkrétních firem a spotřebitelů. I když od spojení mezi firemní sférou a sférou globálního trhu nelze abstrahovat, do jisté míry lze hovořit o specifických problémech korporátní mikroetiky. Mezi katolickými mysliteli tento důraz rozvijí celá řada autorů, z nichž patrně největší pozornost si zaslouží Michael Naughton a Kenneth Goodpaster.

Př́stup Michaela Naughtona volně navazuje na východiska tzv. teologie institucí, zvláštního směru katolického myšlení, který se rozvinul v 70. letech jako určitý mírnější protipól teologie osvobození. ${ }^{42}$ Od zakladatele tohoto směru Roberta K. Greenleafa (1904-1990) Naughton přebírá cenný koncept služebního vi̊dcovství (servant leadership), jehož základem je průběžné ověřování, zda jsou při výkonu firemního řízení v první řadě zajištovány „nejvyšší priority bližních“, pod-

40 Srov. Pierpaolo DONATI, The Morality of Action, Reflexivity and the Relational Subject, in: Distant Markets, Distant Harms: Economic Complicity \& Christian Ethics, ed. Daniel K. FINN, Oxford: Oxford University Press, 2014, s. 70-73.

41 Srov. Daniel K. FINN, Distant Market, Distant Harms, 2014, s. 238.

42 Za zakladatele tohoto teologického směru bývá zpravidla považován Robert K. Greenleaf, na jehož práce navazovali další badatelé, např. Stephen Covey, Peter Senge, Max De Pree aj. 
řízených zaměstnanců, kolegů, zákazníků apod. a zda se lidé díky tomuto řízení „rozvíjejí jako /plnohodnotné/ lidské osoby“, tj. stávají se zdravějšími, svobodnějšími a schopnými v budoucnu sami sloužit druhým. ${ }^{43}$ Služební leader se snaží naslouchat, vcítit se, reflektovat, vystihovat problémy, předvídat, přesvědčovat a budovat firmu nejen jako kolbiště soukromých zájmů, ale jako integrální společenskou komunitu svého druhu. ${ }^{44}$

V knize Leading Wisely in Difficult Times Michael Naughton a David Specht polemizují se soudobým materialistickým a mravně-relativistickým pojetím firemní etiky založené pouze na osobních zájmech každého jednotlivého pracovníka. ${ }^{45}$ Cílem služebního vůdcovství je rozvinout u vedoucího pracovníka schopnost navzdory řešení konkrétních problémů „vidět věci v celku“, „vnímat jejich celistvou přirozenost jako duši a tělo, hmotnou a duchovní, principiální i technickou, založenou na rozumu i víre “" ${ }^{46}$ Naughton a Specht si také kladou otázku, jakým způsobem se v praktické rutině firemního manažera může projevovat křest̉anská víra, a představují tři typologicky odlišné př́iběhy firem, které se ji ve svých cílech a hospodářské činnosti rozhodly uplatnit. Jde o př́běhy spojující mravní charakter leaderů s etickou kulturou jejich institucí a překračující pouhou oblast technických kompetencí a etických kodexů. Tyto př́běhy naznačují, jakým způsobem lze i problémy dnešní složité, soupeřivé a globálně provázané podnikové praxe číst $\mathrm{v}$ perspektivě víry, mravní odvahy a dobrého správcovství (stewardship). ${ }^{47}$

Také Naughtonův kolega Kevin Goodpaster se zabývá převládajícími trendy organizační kultury současných firem a nachází v ní tři druhy patologických rysů: fixaci na jediný účel, „racionalizaci“ (rozumové ospravedlňování eticky nežádoucích aktivit) a mravní rozpolcení (oddělování morálky v osobním a firemním životě). ${ }^{48}$ Jim odpovídají tři druhy etických imperativů, které je potřeba ve firemní kultuře uplatnit, totiž imperativ orientace, institucionalizace a uchovávání „korporátního svědomí“. ${ }^{49}$ Zvláštní pojem korporátního svědomí vysvětluje Goodpaster jako naši polouvědomělou „myšlenkovou mapu“ hospodářské situace, etické tušení širšího rámce „kulturní skutečnosti“, v němž se (navzdory rozhodnutím jednotlivých aktérů) hospodářský život zpra-

43 Srov. Robert K. GREENLEAF, Servant Leadership, A Journey into the Nature of Legitimate Power and Greatness, Mahwah: Paulist Press, 2002, s. 27. Dále viz Robert K. GREENLEAF, Seeker and Servant, Reflections on Religious Leadership, New York: Jossey-Bass, Inc., 1996.

44 Srov. Robert K. GREENLEAF, Servant Leadership, Introduction, s. vi-vii. Požadavek, aby se soukromý podnik kromě oprávněného úsilí o zisk stával také „,solidární komunitou“, formuloval i papež Jan Pavel II. v sociální encyklice Centesimus annus. Sociální encykliky (1891-1991), Praha: Zvon, 1996. Encyklika Centesimus annus, čl. 43. Srov. KSNC 340.

45 Autoři se v této souvislosti kriticky vyjadřují také o relativistickém stylu, kterým v současné době probíhá výuka manažerské ekonomie prostřednictvím tzv. př́padových studií. Michael NAUGHTON - David SPECHT, Leading Wisely in Difficult Times: Three Cases of Faith and Business, Mahwah: Paulist Press, 2011, s. 7-11.

46 Tamtéž, Introduction, s. xi.

47 Tamtéž, s. 4-5. První př́iběh se týká firmy Reell, která musela čelit 35\% výpadku př́ímů v prodeji notebooků v souvislosti s americkou krizí z let 2000-2001. Přes vážné finanční problémy se firma rozhodla nepropouštět zaměstnance a nabídla jim možnost snížení platů odstupňovaného podle dosavadní výše, míry odpovědnosti a zásluh (vysoký management si snížil platy nejvíce). Tím se jí podařilo zachovat atmosféru komunitní soudržnosti a v delším horizontu také hospodářskou prosperitu. Druhý př́iběh líčí chování společ nosti Engineered Products, která čelila silným tržním tlakům na přemístění výroby lisovacích strojů do Číny. Management otevřeně vysvětlil zaměstnancům celý plán přemístění rozložený do deseti měsíců, zapojil je do rozhodování o něm a části zaměstnanců pomohl najít práci v jiných podnicích. Odmítl svá rozhodnutí skrývat pouze za neosobní síly ekonomické globalizace, ale přiznal také svou odpovědnost za dílčí selhání, která mohla přemístění firmy ovlivnit. Třetí příběh se zabývá situací firmy Tomasso Corporation, která do svých firemních cílů prŕmo zakomponovala hodnoty sociálního učení církve. K nejzajímavějším prvkům její firemní kultury patří nap̌r. výroční bonusy sdílené manažery i zaměstnanci, povinné kontaktování propuštěných zaměstnanců dvakrát ročně scílem „usmírení názorových rozdílư“, nezávislý průzkum organizačního klimatu firmy provedený externím partnerem, spirituální ekumenické podpůrné skupiny, dobrovolnická sociální práce zaměstnanců dvakrát ročně, prostor pro tichou reflexi nebo modlitbu před i po důležitých firemních schůzích apod. Srov. Michael NAUGHTON - David SPECHT, Leading Wisely in Difficult Times, s. 94-98.

48 Srov. Kenneth E. GOODPASTER, Conscience and Corporate Culture, Malden: Blackwell Publishing, 2007, s. 25-26. Tyto tři patologické rysy Goodpaster spojuje deštníkovým pojmem „teleopatie“, tj. „nevyváženého sledování určitého cíle“v oblasti myšlenek, tužeb a rozhodování hospodářských aktérů, zejména vedoucích pracovníků. Srov. tamtéž, s. 28-29.

49 Tamtéž, s. 7. 
vidla odehrává. ${ }^{50}$ Korporátní svědomí v sobě spojuje osobní charakter podnikatele se zvyklostmi a praktikami podniku; nemá pouze roli pasivní, ale aktivně také usměrňuje naše jednání a praktickou orientaci. Je na jedné straně nástrojem popisným, diagnostickým, na druhé straně předpisujícím, normativním. Ve druhé z právě zmíněných oblastí Goodpaster dále nachází ještě funkci rozlišující, kritickou a idealizující, která se uplatňuje při stanovení našich hodnot a přesvědčení. ${ }^{51}$

Nejcitlivějším bodem Goodpasterovy úvahy o hospodářském svědomí je vztah mezi rovinou osobní a „organizační“. Goodpaster připouští, že svědomí může mít povahu „sdílené perspektivy“, a rozlišuje jeho tzv. tři polarity: polarita já-druhý, zaujatý-nezaujatý a ideální-reálný. V první polaritě prorážíme „iluzi našeho sobectvi“" uvědoměním a respektováním bližního, v druhé rozšiřrujeme obzor našeho "my“ tak, aby překročil protiklad „my“ a „oni“ a přijal nezaujatou perspektivu „my všichni“, která na etické rovině odpovídá tzv. zlatému pravidlu. Třetí polarita vstupuje do hry ve chvíli, kdy se ptáme, jak si uvědomujeme sebe i bližní v reálné praxi a jak můžeme uskutečnit své ideály v reálném světě, který se tomu staví na odpor. Tuto rovinu podle Goodpastera symbolicky vystihuje věta: „Tohle je náš život. ${ }^{“ 52}$

\subsection{Alternativní pohledy}

Vedle těchto hlavních proudů katolické hospodářské etiky je třeba výběrově zmínit alespoň dvě tvůrčí myšlenkové alternativy. Ve své starší, ale svým obsahem stále aktuální studii From Business Ethics to the Vocation of Business Leaders vychází lovaňský etik Johan Verstraeten z premisy, že podnikání není pouze účelovým jednáním zaměřeným $k$ vnějšímu hospodářskému cíli (zisku), nýbrž svébytnou hospodářskou i etickou praxí. ${ }^{53}$ Podnikatelská etika vyjadřuje zásadní napětí mezi našimi tužbami a jejich hranicemi, imperativy a vizemi dobrého života. ${ }^{54}$ Její základní rovinou je zkoumání firemního étosu, faktických postojů, hodnot a vzorců chování manažerů a zaměstnanců a stejně i faktických důsledků etického chování v oblasti podnikání. Empirické studie mohou na tomto stupni ukázat, do jaké míry se etické jednání hospodářsky vyplácí, i když tento ukazatel nesmí být považován za jediné měřítko jeho posuzování. ${ }^{55}$ Druhou rovinou je hospodářská etika normativní, která však musí být současně etikou praktickou, protože zde nevystačíme s pouhým abstraktním určením žádoucích hodnot, ale musíme se zabývat konkrétními problémy, dilematy a hospodářským jednáním v jeho celku. Klićovou metodou normativní hospodářské etiky je př́padová kazuistika, ovšem ospravedlněná obecnou rozumovou argumentací. Třetí rovinou je praktická moudrost, která bere v úvahu jedinečnost osob a okolností hospodářského jednání, a Verstraeten ji spojuje zvláště s etikou hospodářské organizace. ${ }^{56}$ Čtvrtou rovinou je etika společenské odpovědnosti podniku, kterou Verstraeten chápe jako formu „korporátního občanství, $\mathrm{tj}$. „smlouvy“ uzavřené s celou společností založené na univerzálním respektu k lidským právům. ${ }^{57}$ Nakonec Verstraeten překračuje samotný rámec etiky a spí̌̌e na rovině filosofické

50 Tamtéž, s. 3

51 Srov. tamtéž, s. 34-35. Goodpaster dále hledá souvislost mezi pojmem svědomí jako myšlenkové mapy a aristotelovskou prozíravostí (fronésis), ukazuje vztah svého konceptu k pojetí „angažovaného aktéra“ v ekonomické teorii her apod.

52 Tamtéž, s. 60.

53 Srov. Johan VERSTRAETEN, From Business Ethics to the Vocation of Business Leaders to Humanize the World of Business, Business Ethics. A European Review 2/1998, s. 112.

54 Srov. tamtéž, s. 113-114.

55 Srov. tamtéž, s. 112

56 Srov. tamtéž, s. 113-114. Toto Verstraetenovo schéma je zřetelně inspirováno pojetím etiky francouzského filosofa Paula Ricoeura prezentovaným v knize Paul RICOEUR, Soi-même comme un autre, Paris: Editions du Seuil, 1990.

57 Srov. Johan VERSTRAETEN, From Business Ethics to the Vocation of Business Leaders, s. 117-118. 
a teologické se ptá, jaké jsou širší předpoklady uskutečnění požadavku humanizace podnikání. ${ }^{58}$

Hospodářská etika není pro Verstraetena pouhým předem definovaným receptem na následné správné chování, ale je komplexní výzvou, jak si „ve světle napětí mezi normou a skutečností, vizí a /jejich/ hranic, dovolit utvářet ,prostor svobody“" a „nalézat nejlidštější řešení hospodářských problémů, která jsou za daných okolností možná. “59

Více teologicky laděnou koncepci hospodářské etiky rozvíjí v současnosti ředitel ústřední poradní komise německé biskupské konference pro sociální otázky (KSZ) v Mönchengladbachu Peter Schallenberg. V obsáhlé předmluvě k německému vydání Bruniho a Zamagniho knihy Economia civile Schallenberg podává originální výklad tržního hospodářství z pohledu františkánské tradice a křest̉anské eschatologie. ${ }^{60}$ Františkánská etika, která staví do středu pozornosti chudé, přejímá podle Schallenberga biblický důraz na „postupné přetváření viditelného světa před tváří neviditelné věčnosti“, kterou lze vnímat pouze ve svátosti církve. ${ }^{61}$ Horské kázání ožrejmuje „Vnitřní obrácení pouhé směnné spravedlnosti k lásce bez /jakéhokoliv/ vypočítavého kalkulu“a Stvořitelova láska je „jediným všeobsáhlým ano k potřebnosti člověka a jeho světa“. ${ }^{2}$ Součástí tohoto světa jsou také trhy, které křestan nemá opouštět, ale „proměňovat je v nástroje /vlastního/ obrácení a zlepšování světa“ skrze jedince, kteří vyhlížejí druhý př́íchod Kristův. Jejich čekání se děje s vědomím, že Kristus zároveň už přišel, a to především v chudých a trpících, což povzbuzuje motivaci k naléhavému etickému jednání ve smyslu „zde a nyní je poslední hodina jednání“.63 Křest’anská hospodářská etika je proto „ke světu obrácená strana eschatologie“. ${ }^{64}$

\section{Závěr}

V klíčovém článku 331 Kompendia sociální nauky církve se zdůrazňuje vnitřní sounáležitost mezi morálkou a ekonomikou, která nás nutí zohlednit také ekonomické argumenty v etice a nejen naopak. ${ }^{65}$ Encyklika Caritas in veritate pro změnu požaduje, aby se etika týkala „všech fází hospodářské činnosti“ i jejích nejběžnějších projevů. ${ }^{66} \mathrm{~V}$ předchozím výkladu jsme ukázali, jak je vnitřní spojitost mezi ekonomikou a morálkou vnímána v různých koncepcích katolické hospodářské etiky. I nadále však zůstává otázkou, jak tento požadavek konkrétně uskutečnit v naší každodenní žité zkušenosti.

Nejprve je třeba si přiznat, že o konkrétní podobě tohoto vztahu zpravidla nerozhodují utopické modely teoretických ekonomů ani soudné stolice věhlasných moralistů, ale praktická rozhodnutí lidské prozíravosti. Většina hospodářských rozhodnutí se odehrává v šedé zóně kompromisů mezi našimi mravními ideály a strategickými tlaky, jimž jsme vystaveni, a podléhá proměnlivé dynamice osobního, pracovního a občanského života. Jak už jsme v úvodu naznačili, k nejrea-

58 Srov. tamtéž, s. 118.

59 Tamtéž.

60 Peter SCHALLENBERG, Einführung zur deutschen Ausgabe: Die franziskanische Spiritualität und eine christliche Moralökonomie, in: Zivilökonomie. Effizienz, Gerechtigkeit, Gemeinwohl, Luigino BRUNI - Stefano ZAMAGNI, s. 13-29. Srov. pozn. č. 9 této studie.

61 Tamtéž, s. 20-21.

62 Tamtéž, s. 21-22.

63 Tamtéž, s. 26-27.

64 Tamtéž, s. 28.

65 KSNC 331. Článek 332 uvádí, že efektivně vyrábět hospodářské statky je mravní povinností, protože jinak by se jednalo o jejich plýtvání.

66 CV 36, 37. 
lističtější formě katolické etiky hospodářství lze dospět analýzou paradoxních krajností mravně-hospodářského života, tj. možnosti dobrého jednání pod tlakem stále rostoucího zisku a možnosti hospodářské rozvahy v situaci maximální duchovní svobody a solidarity. K nim můžeme přiřadit určité typické role, které mohou představovat např. finanční makléř a asketicko-dobročinně jednající světec. Prokážeme-li, že jsou etický a ekonomický postoj slučitelné v těchto krajních polohách, nemůžeme je ignorovat ani ve zcela běžné realitě našeho života.

Hlavním důvodem přitažlivosti práce burzovního makléře je možnost přijmout svobodnou perspektivu hráče, který je neustále vystaven př́ležitostem k aktivnímu jednání, a na toto jednání získává okamžitou odezvu. S naléhavostí jednat jsou spojena typická rizika zbrklosti, roztěkanosti, stádovitosti, podléhání vášním a také morálního pragmatismu, který omlouvá určitou míru lidské bezohlednosti nedostatkem času k rozhodování. Nedávná světová finanční krize však ukázala v plné nahotě, že ani „virtuální sektor“ se nemůže spoléhat jen na matematické vzorce, statistické předpovědi a okamžitou intuici, ale musí se vystavit ostrému světlu širší lidské reality. Zastírání skutečných rizik a důsledků spekulativních transakcí ve společném světě nemusí vést pouze $\mathrm{k}$ narušení důvěry a mezilidských vztahů, ale také $\mathrm{k}$ rychlé ztrátě onoho bohatství a svobody, o něž notoričtí hráči primárně usilují.

Navzdory různým etickým kodexům je proto třeba přijmout určité morální brzdy, které by zkušeným praktikům bránily upadnout do pohodlí cynismu a umožnily jim důstojně čelit typickým konfliktům zájmů, zachovat si zároveň tvář i hospodářskou účinnost své práce. Britský novinář Brian Bloch tyto brzdy formuluje takto: 1. jsi-li na pochybách, jasně to přiznej; 2 . hledej řešení na míru lidské osobě; 3. nečekej, že se zeptá klient, zeptej se sám; 4. bud zcela konkrétní $\mathrm{v}$ otázce rizik plynoucích $\mathrm{z}$ dané transakce; 5. průběžně informuj klienta o změně situace na trhu; 6. ujisti se, že klient tvému sdělení rozumí. ${ }^{67}$ Katolická etika může $k$ těmto zásadám přidat požadavky ještě náročnější: 7. bud' svobodný od majetku a služ jím; 8. ptej se po smyslu užívání statků a odpovědně je sdílej; 9. zvažuj dobro všech, kdo jsou dotčeni tvým jednáním; 10. nenič důstojnost konkurenta, ale uč se od něj; 11 . i v „zištnosti“ bud' nezištný; 12. snášej všednost a hledej v ní své povolání; 13. řid’ druhé tak, aby ze sebe mohli vydat to nejlepš́; 14. i v nejhlubší krizi hledej naději a jdi jí naproti.

Na druhé straně ani nejobětavěǰsí světec nemůže žít pouze z neustálého proudu obdržených darů a zázraků, ale musí se nutně ptát, jaké mají jeho láska a dobro skutečný lidský dopad. Každý upř́mně milující a duchovně žijící člověk si je vědom úskalí plynoucího z dvojznačnosti každého lidského jednání, jeho možných špatných důsledků a mnohostranné závislosti na jednání ostatních lidí. Radikální svoboda od majetku nevylučuje, ale spíše vyžaduje rozumové zvažování toho, nač $\mathrm{v}$ omezeném čase vynaložit své schopnosti, energii a zdroje a jak je nejlépe skloubit s možnostmi, úmysly a zájmy druhých lidí, kteří jsou stejně křehcí, nedokonalí a smrtelní jako světec sám. Sebenezávislejší asketa nemůže považovat za samozřejmé, že druzí jeho př́stup automaticky pochopí a přijmou, ale musí se pokorně vystavit diskusi o tom, co je dobré nejen z jeho hlediska, ale také z pohledu komunity a občanské pospolitosti jako celku. Ani heroismus světce se tak zcela nevymyká požadavku na taktické plánování, racionalitu a hospodářskou efektivnost. ${ }^{68}$

67 @ Investopedia, L.L.C., 8 Ethical Guidelines (on-line), dostupné na: http://www.investopedia.com/articles/financialcareers/08/broker-ethics-tips.asp, citováno dne 22. 7. 2016.

68 Ve volné návaznosti na francouzského filosofa a jezuitu Michela de Certeau zde můžeme rozlišit mezi strategií a taktikou „hospodářské lásky“. Zatímco strategie s milovaným kalkuluje a utužuje vzájemný vztah záměrným vyvažováním hospodářské jistoty a nejistoty, taktika spojuje vlastní postavení s postavením druhého, aniž by ho chtěla ovládat. Nenárokuje si předem, co jí patří, ale přesto aktivně vyhližzi a využívá momentálně nabídnutých příležitostí ke společnému prospěchu všech, za které jsem spoluodpovědný (C) Blog la WordPress.com (on-line), dostupné na: https://chisineu.files.wordpress.com/2012/10/certeau-michel-de-the-practice-of-e- 
Křestanská láska je za všech okolností současně výzvou k obezřetnosti a realismu, který nezveličuje naše možnosti a „kalkuluje“ s tím, že spása vždy přichází skrze lidskou nedokonalost. Křestanský realismus se přesto neprojevuje mravním kompromisnictvím a ústupností vůči materiálním pokušením, ale spíše důvěrou, že Boží Slovo je vždy hlubším základem skutečnosti než to, co se v ní momentálně staví na odiv, včetně brutálních výkyvů finančních trhů a hospodářských nespravedlností. ${ }^{69}$ Nesklouzává však ani k laciné „spiritualizaci“ a „etizaci“ hospodářských problémů, nýbrž uznává nutnost čelit lidské nedokonalosti také rozvážným kladením právních překážek a budováním kontrolních politických institucí tržního hospodářství. Katolická etika hospodářství je v tomto smyslu vždy zároveň etikou hospodářské svobody i etikou občansko-politickou.

Nejtěžším úkolem je formulovat její nároky v pluralitě příběhů našeho osobně-komunitního života, kde se musíme spokojit pouze s rámcovým popisem typických možností a dilemat. Středem našeho hospodářsko-etického života je nesporně otázka povolání, v níž se snoubí moment lidského hledání a daru, který může být v napětí vůči našim přirozeným schopnostem a slabostem. Druhým momentem je vratké a neustálé hledání rovnováhy mezi rodinným a pracovním životem a také úsilím o hledání osobního i sdíleného štěstí. Momentální podoba této rovnováhy je vždy současně měřítkem naší hospodářské racionality i úcty k vlastnímu lidství. Do této oblasti spadá také hledání uvážlivé a přiměřené míry majetkového vlastnictví a lidské spotřeby.

Třetí rovinou skloubení hospodářského a mravního života je sféra zaměstnání nebo firmy chápané v katolické etice vždy zároveň jako lidská komunita svého druhu. Jde o sféru, kde musím vidět vlastní cíle $\mathrm{v}$ cílech ostatních, moment potřebnosti a služby přímo ve vlastním prospěchu, kde se musím učit „soupeření v lásce“ a „jednotě ve sporu“ a kde přes všechnu oprávněnost lidského střetávání musí převážit naslouchání „odcizeným bližním“. Je to také oblast života, v níž se musím kriticky vyrovnávat s bolestným napětím svobody a autority, osobní seberealizace a hospodářského útlaku, křivdy a utrpení. Toto napětí není z lidského života plně odstranitelné, přesto je však jen odvrácenou tváří mé vlastní odstupňované spoluodpovědnosti za celek podnikání a podniku, která se nevyčerpává jen splněním mého úkolu, ale překračuje ho společným hledáním smyslu společné práce v pluralitě názorů a perspektiv. Čtvrtou rovinou konkrétní hospodářské etiky je rovina tzv. „hospodářské demokracie“, kdy hledáme antropologickou souvislost své firmy se všemi občany a lidmi, kteří jsou naší prací a podnikáním dotčeni. Zohledňujeme zde také otázky spravedlnosti a lidských práv, trvalé udržitelnosti a ekologie, kulturní identity a ohledu na společný svět, který byl dán všem bez rozdílu ke společnému užívání.

Existuje však ještě hlubší spojitost mezi etikou a hospodářskou racionalitou. Dobře hospodařit vždy v posledku znamená „směňovat“ s Bohem, se sebou is bližními sám sebe. Je to směna krajně paradoxní, v níž se kloubí nutnost se svobodou, prospěch s nezištností, zápolení se spoluprací a tíživost se seberealizací. Probíhá však ve všech momentech, kdy z důvodu odpovědnosti za sebe, svou rodinu a bližní v potu tváře neseme úděl své existence a zároveň se snažíme v něm zahlédnout otisk smyslu, radosti a vykoupeného lidství. O to naléhavěji pro nás i v hospodářské oblasti platí Kristovo slovo, že jakou měrou měříme, takovou se naměří i nám. A to, co lidským měřením vyjádřit nelze, nám teprve potom snad bude přidáno. 


\section{Solidární zisk a efektivita lásky. Motivy současné katolické etiky tržního hospodářství}

\section{Abstrakt}

Na podkladě interpretace významných proudů současné katolické etiky hospodářství článek zkoumá různé přistupy $\mathrm{k}$ překonávání deficitu hospodářské racionality $v$ oblasti morálky a mravního deficitu v oblasti tržního hospodářství. Snaží se tak odpovědět na klíčovou otázku, zda a v jaké podobě je v současné globální ekonomické praxi možná hospodářská etika a jak k ní může specificky přispět katolické sociální myšlení a tradice.

Klíčová slova: morálka a ekonomika, etika hospodářství, ekonomika daru, katolický libertarianismus, katolický sociální reformismus, sociálně-tržní hospodářství, kritický realismus, mikroetika firemního života, globální hospodářská krize, hospodářsko-etická praxe, eschatologie hospodářského rozvoje, směna lidské svobody

\section{Kontakt na autora}

\section{Mgr. Vojtěch Mašek, Ph.D.}

Univerzita Karlova

Katolická teologická fakulta, Katedra teologické etiky a spirituální teologie

Thákurova 3, 16000 Praha 6

vojtech.masek@seznam.cz 